\title{
P.B. Марушко
}

\section{Стандарти істотної еквівалентності між системами акредитації безперервного професійного розвитку}

ДУ «Інститут педіатрії, акушерства і гінекології імені академіка О.М. Лук'янової НАМН України», м. Київ Modern Pediatrics. Ukraine. 4(108): 7-13. doi 10.15574/SP.2020.108.7

For citation: Marushko RV. (2020). Standards of substantive equivalence between accreditation systems for continuous professional development. Modern Pediatrics. Ukraine. 4(108): 7-13. doi 10.15574/SP.2020.108.7.

Висвітлено повідомлення про створення міжнародних стандартів акредитації безперервної медичної освіти / безперервного просесійного розвитку (БМ0/БПР) медичних працівників. Ініціатором є Міжнародна академія акредитації БПР, а запропоновані стандарти розроблені у співпраці 3 міжнародними організаціями, які займаються питаннями акредитації в різних країнах.

Мета - встановити сфери та критерії істотної еквівалентності для визнання в системах акредитації БПР та між ними. Таке визнання покликане допомогти міжнародним акредитаційним організаціям під час розробки акредитаційних вимог до освіти лікарів та інших категорій медичних працівників, а також визначити лідерів, які б взяли участь у створенні нових та розбудові існуючих систем акредитації БПР шляхом надання орієнтирів основних складових в їхніх системах акредитації.

Автор заявляє про відсутність конфрлікту інтересів.

Ключові слова: акредитація, безперервний професійний розвиток, освітня діяльність, лікарі.

\section{Standards of substantive equivalence between accreditation systems for continuous professional development \\ R.V. Marushko}

SI «Institute of Pediatrics, Obstetrics and Gynecology named of academician 0.M. Lukyanova NAMS of Ukraine», Kyiv

The article highlights the report on the implementation of international standards for accreditation of continuing medical education/continuing professional development (CMO/CPD) of health professionals. The initiator is the International Academy of Accreditation for CPD, and the proposed standards have been developed in collaboration with international organizations dealing with accreditation in various countries.

Purpose - to establish areas and criteria of substantive equivalence for recognition in and between CPD accreditation systems. This recognition is intended to assist international accreditation organizations in developing accreditation requirements for the education of physicians and other categories of health professionals, and in identifying leaders involved in creating new and re-building existing CPD accreditation systems by providing guidance on the key components used in their accreditation systems.

No conflict of interest were declared by the author.

Key words: accreditation, continuous professional development, educational activity, doctors

\section{Стандарты существенной эквивалентности между системами аккредитации непрерывного профессионального развития \\ P.В. Марушко}

ГУ «Институт педиатрии, акушерства и гинекологии имени академика Е.М. Лукьяновой НАМН Украины», г. Киев

Представлено сообщение о создании международных стандартов аккредитации непрерывного медицинского образования/непрерывного профессионального развития (НМО/НПР) медицинских работников. Инициатором является Международная академия аккредитации НПР, а предложенные стандарты разработаны в сотрудничестве с международными организациями, которые занимаются вопросами аккредитации в разных странах.

Цель - определить ссреры и критерии существенной эквивалентности для признания в системах аккредитации НПР и между ними. Такое признание призвано помочь международным аккредитационным организациям при разработке аккредитационных требований к образованию врачей и другим категорий медицинских работников, а также определить лидеров, которые бы участвовали в создании новых и развитии существующих систем аккредитации НПР путем предоставления ориентиров основных составляющих в их системах аккредитации. Автор заявляет об отсутствии конфрликта интересов.

Ключевые слова: аккредитация, непрерывное профессиональное развитие, образовательная деятельность, врачи.

\section{Вступ}

Тннуючі світові системи акредитації в рамках безперервного професійного розвитку (БПР) постійно сприяють вдосконаленню компетентності та ефективності роботи медичних працівників та в організаціях, в яких вони надають медичну допомогу пацієнтам [3,8,9].

Клініцисти найкраще навчаються, якщо можуть обирати з великого різноманіття освітньої діяльності та форматів те, що є актуальним і відповідає їхнім потребам [1,5,7].

Оскільки вибір та різноманітність є ключовими для задоволення освітніх потреб лікарів, відомі міжнародні організації, які займаються питаннями акредитації БПР, постійно докладають цілеспрямованих, узгоджених зусиль для визначення принципів, що можуть бути основою для створення та впровадження істотної, або суттєвої, еквівалентності між системами акредитації БПР. Істотна еквівалентність призначена для підтримки мобільності лікарів, дає їм змогу отримати доступ до акредитованих навчальних занять, що визнаються різними системами акредитації БПР таким чином, щоб максимально підвищити значення цих систем акредитації і мінімізувати при цьому тягар дотримання їхніх вимог [4].

Міжнародна академія акредитації БПР розробила загальний набір міжнародних стандартів для керівництва акредитацією безперервної медичної освіти / безперервного професійного розвитку (БМО/БПР) медичних спеціалістів 
для поширення у всьому світі. Ці стандарти будуть також використовуватися для визначення істотної еквівалентності між акредитаційними організаціями.

Істотна еквівалентність між акредитаційними організаціями дає змогу зацікавленим сторонам - національним органам виконавчої влади, акредитаційним, а також організаціям, які проводять атестацію / сертифікацію, провайдерам БМО/БПР і, найголовніше, лікарям та їхнім пацієнтам - знати, що акредитована освіта, спрямована на удосконалення та поліпшення надання медичної допомоги та забезпечення безпеки пацієнтів, відповідає одному і тому самому рівню, є незалежною, науковообгрунтованою, актуальною, якісно розробленою, а також оцінює результати освітніх заходів [6]. Додатковою перевагою є можливість укладання угод про визнання кредитів в юрисдикціях, що використовують кредити як винагороду за участь у БМО/БПР.

\section{Передісторія створення стандартів}

Міжнародна академія акредитації БПР провела значну підготовку, починаючи з розробки початкового набору стандартів [2] та аналізу літератури, що висвітлює найефективніші системи акредитації БПР, а також використала оригінальний набір стандартів еквівалентності, розроблений Акредитаційною радою з питань безперервної медичної освіти (США) і Королівським коледжем лікарів та хірургів Канади. Ці стандарти еквівалентності використовуються вже понад 20 років як механізм експертної оцінки між акредитаційними органами, а також укладання угод про взаємодію між акредитаційною і кредитною системами.

Наступним кроком було проведення електронного опитування з використанням модифікований процесу Delphi [2] великих груп акредитаційних органів та регулюючих організацій, як членів, так і не членів Міжнародної академії акредитації БПР. У ході опитування учасникам запропонували вказати свій рівень згоди із запропонованими стандартами, що складаються 3 шести доменів і стандартів для кожного 3 доменів, а також доповнити або модифікувати будь-які відсутні домени i/або стандарти.

Результати опитування представлені на Кельнській конференції в Берліні 16 травня 2019 року і на конференції Кельнського консенсусу в Кельні, Німеччина, 13-14 вересня 2019 року. Використовуючи відгуки, отримані на Берлінській нараді і Кельнській конфе- ренції, робоча група Міжнародної академії акредитації БПР розробила другий варіант стандартів, представлений на Європейському форумі безперервної медичної освіти в Манчестері, Англія, 6-8 листопада 2019 року.

Останнім етапом стало схвалення останнього (третього) варіанту стандартів основної еквівалентності представниками органів, які акредитують, і регулюючих організацій, керівники яких є членами Міжнародної академії акредитації БПР. Крім того, важливо було визначити, як найкраще розповсюдити та впровадити стандарти серед акредитаційнихта регулюючих організацій повсюдно. Конференція Кельнського консенсусу, 10-11 вересня 2020 року в Чикаго, штат Іллінойс, присвячена саме питанням впровадження стандартів.

У результаті проведеної роботи Міжнародна академія акредитації БПР запропонувала шість доменів стандартів для визначення і визнання основної еквівалентності органами, які акредитують БМО/БПР:

Домен 1: Права і обов'язки органу, який акредитуе

Цей домен визначає організації, які мають право розробляти і впроваджувати системи акредитації БПР, і стандарти, що описують адміністративну роль і обов'язки органу, який акредитує.

Домен 2: Незалежність та прозорість акредитованого навчання

Цей домен фокусується на вимогах, спрямованих на забезпечення того, щоб освітня діяльність розроблялася і здійснювалася незалежно від впливу комерційних інтересів, що визначаються як будь-яка організація, яка виробляє, продає, перепродує або розповсюджує медичні товари або послуги, що споживаються пацієнтами або використовуються ними.

\section{Домен 3: Оцінка потреб при плануванні} акредитованої освіти

Цей домен розглядає різні джерела даних для визначення освітніх потреб окремих лікарів і медичних колективів.

\section{Домен 4: Валідність контенту в акреди- тованому навчанні}

Цей домен фокусується на процесах розробки контенту для акредитованої освіти, який відображає останні досягнення в галузі наукових даних i технологічних досягнень для постійного підвищення якості та безпеки медичної допомоги пацієнтам.

\section{Домен 5: Якість освітнього проєктування} в акредитованій освіті 
Цей домен розглядає ефективність розробки освітніх форматів відповідно до виявлених потреб передбачуваної цільової аудиторії.

\section{Домен 6: Результати акредитованої освіти}

Ця область фокусується на оцінці ефективності та освітнього впливу акредитованої освіти на знання, компетентність або ефективність роботи лікарів і/або стан здоров'я пацієнтів.

Стандарти суттєвої еквівалентності між системами акредитації БПР

Домен 1: Права і обов'язки органу, який акредитує

Основною метою БПР є сприяння постійному підвищенню компетентності та ефективності роботи лікарів у забезпеченні зразкового медичного обслуговування пацієнтів. Системи акредитації призначені для обслуговування лікарів і медичних колективів, акредитована освіта відповідає встановленим стандартам акредитації.

3 огляду на важливість акредитації для поліпшення медичного обслуговування пацієнтів фармацевтична або приладобудівна промисловість або інші комерційні інтереси не мають права бути органами, які акредитують.

Право організації функціонувати як орган, який акредитує, і стандарти, що визначають його роль і обов'язки, перераховані нижче:

\section{Стандарти}

\section{1. Орган, який акредитує, має бути:}

I) юридичною особою;

II) керуватися медичною професією наразі або в перспективі;

III) підзвітним громадськості за допомогою прозорої звітності про управління, акредитаційні рішення і фінансування на регулярній основі.

\section{2. Орган, який акредитує, не має бути:}

I) комерційним інтересом або будьяким підприємством, яке перебуває під прямим або непрямим контролем комерційного інтересу, що визначається як будьяка організація, яка виробляє, продає, перепродує або розповсюджує медичні товари або послуги, що споживаються пацієнтом або використовуються ним;

II) під прямим або непрямим контролем або впливом професійної лобістської організації, наукового товариства / асоціації, акредитованого провайдера, організатора акредитованої освіти щодо управління, фінансів, правил і процедур процесу акредитації, якщо тільки не створені відповідні захисні заходи для забезпечення відсутності впливу або упередженості як результат цих ролей;
III) контрольованим виключно окремими особами як зацікавленими сторонами для особистої вигоди.

1.3. Орган, який акредитує, повинен:

I) визначати, які організації мають право подавати заявку на акредитацію;

II) визначати та інформувати про справедливий i прозорий процес акредитації, який включає експертну оцінку з боку медичних працівників та належні процесуальні гарантіі, включаючи процес подання скарг і процес перегляду та апеляції;

III) вимагати від організацій, що претендують на акредитацію або повторну акредитацію, надання як опису відповідності, так і демонстрації відповідності, тобто результатів діяльності на практиці;

IV) проводити регулярний аудит або перевірки акредитованих провайдерів БМО та їх акредитованої освітньої діяльності;

V) взаємодіяти з акредитованими провайдерами БМО і організаторами акредитованої освіти для поліпшення іх обізнаності щодо вимог акредитації та розвитку високоякісної незалежної освіти для лікарів;

VI) вимагати від акредитованих провайдерів БМО або організаторів акредитованої освіти поліпшення напрямків, визнаних як невідповідні вимогам акредитації;

VII) забезпечувати, щоб рішення про акредитацію, а також супровідна документація велися органом, який акредитує, відповідно до чинного національного законодавства або професійних ліцензійних вимог;

VIII) забезпечувати, щоб акредитовані провайдери БМО або організатори акредитованої освіти зберігали записи, пов'язані з дотриманням вимог акредитації, а також завершенням навчання протягом періоду, визначеного органом, який акредитує.

Домен 2: Незалежність та прозорість акредитованого навчання

Оскільки в медичній професії та поза нею існує багато конкуруючих інтересів, що перешкоджають раціональному і заснованому на фактичних даних прийняттю рішень в охороні здоров'я, необхідно докласти всіх зусиль для забезпечення незалежності та прозорості акредитованої освіти.

Орган, який акредитує, відіграє вирішальну роль у встановленні стандартів відповідності, що забороняють комерційним інтересам (суб'єктам, які виробляють, продають, перепродують або розповсюджують медичні товари або 
послуги, що споживаються або використовуються пацієнтами) домагатися акредитації та проведення політики, яка забороняє контроль, вплив або участь у плануванні, реалізації та оцінці акредитованої освіти комерційних інтересів.

Якщо фінансування (комерційна підтримка) надається комерційними інтересами для компенсації витрат на акредитоване освіту, то це фінансування має здійснюватися прозоро і розкриватися учням.

\section{Стандарти}

2.1. Орган, який акредитує, має вимагати від акредитованих провайдерів БМО або організаторів акредитованого навчання виконання того, що:

I) комерційні інтереси не мають жодного впливу, контролю або участі в плануванні, розробці контенту, виборі освітніх методів, виборі того, хто може надати цей контент, виборі цільових аудиторій, презентації контенту або в будь-якому іншому аспекті надання або оцінки акредитованої освіти;

II) усі особи, які беруть участь у плануванні та розробці, презентації (в усній або письмовій формі) або оцінці акредитованого навчання, розкривають наявність або відсутність відповідних взаємозв'язків (конфліктів інтересів) 3 комерційними інтересами;

III) акредитований провайдер БМО активно мінімізує ризик того, що відповідні взаємозв'язки можуть впливати на зміст (упередженість) акредитованої освіти;

IV) учнів інформують про наявність або відсутність відповідних взаємозв'язків (конфліктів інтересів) ті, хто контролює контент (при плануванні та викладачі), змістовно та своєчасно без включення будь-якої реклами (corporate branding).

2.2. Орган, який акредитує, має вимагати від акредитованих провайдерів БМО або організаторів акредитованого освіти забезпечення нижчезазначених умов:

I) умови і способи оплати комерційної підтримки, що визначається як фінансова або натуральна підтримка з боку суб'єктів, які виробляють, продають, перепродають або розповсюджують медичні товари або послуги, що споживаються або використовуються пацієнтами, акредитованої освіти, мають відповідати національним правовим вимогам, зокрема податковому та антикорупційному законодавству, а також професійному законодавству;

II) якщо професійне законодавство забороняє комерційну підтримку, то вона не може використовуватися;
III) надання комерційної підтримки ніколи не може бути відносинами між окремими учнями і комерційним спонсором;

IV) якщо акредитований провайдер БМО або організатор акредитованої освіти погоджується на використання комерційної підтримки, акредитований провайдер БМО або організатор акредитованої освіти зберігає контроль за визначенням освітніх потреб, вибором професорсько-викладацького складу, вибором цільової аудиторії і всіма іншими аспектами при плануванні, реалізації освітнього контенту і оцінки результатів освітньої діяльності;

V) комерційна підтримка не використовується для оплати особистих витрат (таких як проїзд, проживання, гонорари або реєстраційні збори) окремих учнів;

VI) учні отримують інформацію до початку акредитованої освіти в разі комерційної підтримки, включаючи джерело комерційної підтримки;

VII) якщо дозволяються рекламна або торговельна діяльність, наприклад, виставки під час акредитованого навчання, то ці заходи мають проводитися окремо від місця акредитованої освіти, і від учнів ніколи не потрібно вимагати участі в такій діяльності.

2.3. Орган, який акредитує, має оцінювати дотримання акредитованими провайдерами БМО або організаторами акредитованої освіти вимог, викладених у стандартах 2.1 i 2.2.

Домен 3: Оцінка освітніх потреб при плануванні акредитованої освіти

Оцінка освітніх потреб є важливою складовою у плануванні, реалізації та оцінюванні акредитованої освіти. Органи, що акредитують, схвалюють оперативне і всебічне планування освітніх заходів, яке дозволяє виявити і задовольнити нагальні потреби учнів. Ці органи також розробляють вимоги, які забезпечують розвиток акредитованої освіти на основі аналізу потреб лікарів, пацієнтів і громад. Освітні потреби можуть бути визначені з різних джерел даних, у тому числі враховуються потреби, що пропонуються лікарями та медичними колективами, прогалини / недоліки в їхній практичній діяльності, оцінка стану здоров'я пацієнтів і населення. Акредитоване навчання, розроблене для задоволення цих потреб, може охоплювати широке коло компетенцій / здібностей, що стосуються професійної діяльності лікарів.

\section{Стандарти}

3.1. Орган, який акредитує, має вимагати від акредитованих провайдерів БМО або 
організаторів акредитованої освіти забезпечення того, що виявлені потреби:

I) визначені на основі аналізу одного або декількох із таких джерел даних:

а) заявлених потреб цільової аудиторії;

б) стану здоров'я окремих пацієнтів, громад або населення;

в) прогалин у знаннях лікарів;

г) зміни / різниці в знаннях, компетентності чи працездатності/ефективності праці лікарів);

г) зміни / різниці в системах догляду за пацієнтами;

д) зміни / різниці працездатності/ефективності праці лікарів;

II) задокументовані;

III) використовуються для інформування навчального дизайну акредитованої освіти;

IV) використовуються тими, хто відповідає за розробку контенту;

V) використовуються для аналізу або оцінки акредитованої освіти.

3.2. Орган, який акредитує, має оцінювати дотримання акредитованими провайдерами БМО або організаторами акредитованої освіти вимог, викладених у стандарті 3.1.

Домен 4: Валідність контенту в акредитованому навчанні

Зміст, представлений в акредитованій освіті, має відображати останні досягнення в галузі медичної науки і технологічних досягнень, що стосуються практики медицини для постійного підвищення якості і безпеки надання медичної допомоги пацієнтам.

\section{Стандарти}

4.1. Орган, який акредитує, має вимагати, щоб акредитовані провайдери БМО або організатори акредитованої освіти забезпечували, що представлений зміст/контент:

I) є релевантним та відповідає виявленим освітнім потребам цільової аудиторії;

II) розглядає коло компетенцій, що стосуються медичної практики;

III) надає рекомендації, засновані на найвищому рівні наявних наукових доказів;

IV) збалансований шляхом інформування учнів про потенційні вигоди і ризики, особливо якщо зміст заснований тільки на експертній думці;

V) не знаходиться під впливом або контролем комерційних інтересів.

4.2. Орган, який акредитує, має оцінювати дотримання акредитованими провайдерами БМО або організаторами акредитованої освіти вимог, викладених у стандарті 4.1.
Домен 5: Якість освітнього проєктування / планування в акредитованій освіті

Планування має вирішальне значення для реалізації ефективної освіти. За даними літератури, навчання дорослих тоді краще, коли освіта є мультимодальною (використання цифрових, мультимедійних технологій), епізодичною (заснованою на формуванні ініціативи учня) й інтерактивною. Адаптивна освіта (заснована на індивідуальних здібностях і потребах) забезпечує кращі результати і вдосконалення учнів. Освітній формат акредитованої освіти має відображати передбачувані результати. Наприклад, удосконалення практичних навичок із використанням тільки дидактичних лекцій менш ефективне за навчання, засноване на формуванні практичних навичок. Навчання на робочому місці має заохочуватися і підтримуватися органами, які акредитують.

Стандарти

5.1. Орган, який акредитує, має вимагати, щоб акредитовані провайдери БМО або організатори акредитованої освіти враховували при плануванні акредитованої освіти:

I) вирішення виявлених потреб;

II) використання освітніх форматів, які б сприяли ефективнішому навчанню і змінам у практичній діяльності;

III) надання нових знань, практичних навичок та компетенцій з метою реалізації на практиці;

IV) сприяння усвідомленому ставленню і задоволенню від навчання в освітньому середовищі.

5.2. Орган, який акредитує, має оцінювати дотримання акредитованими провайдерами БМО або організаторами акредитованої освіти вимог, викладених у стандарті 5.1.

Домен 6: Результати акредитованої освіти

Оцінка впливу або результати акредитованої освіти дають змогу акредитованому провайдеру БМО або організатору акредитованої освіти визначати, чи була освіта ефективною, і виявляти додаткові освітні потреби.

\section{Стандарти}

6.1. Орган, який акредитує, має вимагати від акредитованих провайдерів БМО або організаторів акредитованої освіти забезпечення того, що акредитована освіта:

I) використовує один або декілька методів оцінки (кількісних і/або якісних) відповідно до цілей або результатів акредитованої освіти;

II) оцінює поліпшення знань, практичних навичок, компетенцій i/або намірів змінити практичну діяльність під час і/або після участі в акредитованому освітньому заході; 
III) оцінює покращення практичної діяльності учнів (там, де це може бути застосовано);

IV) оцінює поліпшення стану здоров'я пацієнтів (там, де це може бути застосовано).

6.2. Орган, який акредитує, має оцінювати дотримання акредитованими провайдерами БМО або організаторами акредитованої освіти вимог, викладених у стандарті 5.1.

\section{Словник}

Акредитована освіта - освітня діяльність, що планується, реалізується й оцінюється відповідно до політики органу, який акредитує.

Акредитований провайдер безперервної медичної освіти (БМО) - організація, уповноважена органом, який акредитує, взяти на себе відповідальність і зобов'язання за розвиток акредитованої БМО.

Орган, який кредитує - організація, яка встановлює і забезпечує дотримання стандартів щодо діяльності безперервної медичної освіти i/або організацій, що надають безперервну медичну освіту (провайдери БМО) шляхом розгляду і затвердження організацій або заявок на надання БМО, а також контролю і забезпечення дотримання керівних настанов цими організаціями або освітньою діяльністю.

Комерційний інтерес - будь-яке підприємство, яке виробляє, продає, перепродує або розповсюджує медичні товари і послуги, що споживаються пацієнтами або використовуються ними.

Комерційна підтримка - грошові або натурні внески, що надаються комерційним інтересом провайдеру БМО, які використовуються для оплати всіх або частини витрат на діяльність БМО.

Компетентність - (використовується як термін для оцінки ефективності навчання) ступінь, в якому лікарі можуть показати, як робити те, чому вони навчились у рамках навчального заходу.

Безперервна медична освіта (БМО) - процес, в рамках якого медичні працівники беруть участь у діяльності, призначеній для підтримки їхнього постійного професійного розвитку. Діяльність заснована на кількох областях навчання, орієнтована на медичних працівників і підтримує їхню здатність надавати високоякісну, всебічну і безперервну допомогу та обслуговування пацієнтів для громадськості або своєї професії. Зміст БМО може бути зосереджений не тільки на клінічній допомозі, але й на тих відносинах/навичках, які необхідні для того, щоб людина могла зробити свій внесок як ефективний адміністратор, викладач, дослідник і член колективу в систему охорони здоров'я. Примітка: БМО та БПР часто вживаються як взаємозамінні терміни.

Провайдер безперервної медичної освіти організація, яка має відповідальність і зобов'язання за розвиток акредитованої БМО.

Безперервний професійний розвиток (БПР) процес навчання медичного працівника, оскільки він/вона прагне підвищити свою компетентність і досвід. Цей процес навчання підтримується постійною медичною освітою та іншою особистою / професійною діяльністю учня з метою надання безпечних, у рамках закону та високоякісних послуг, спрямованих на поліпшення результатів здоров'я пацієнтів та громади. Примітка: БПР та БМО часто вживаються як взаємозамінні терміни.

Кредит / Бали - винагорода за участь в акредитованій діяльності БМО. Лікарі та інші медичні працівники використовують кредити/бали для задоволення вимог до підтримки ліцензування, сертифікації/атестації, членства в професійних товариствах та інших професійних привілеїв.

Незалежність в БМО/БПР - усі елементи планування, розробки та реалізації освітньої діяльності не контролюються / вільні від контролю комерційного інтересу і/або будь-якого іншого небажаного впливу.

Знання - (вживаються як термін для оцінки ефективності навчання) ступінь, в якій лікарі здобули знання, надані в ході навчання.

Оцінка потреб - метод(и), який використовується (i) для виявлення усвідомлених і неусвідомлених потреб ідентифікованої цільової аудиторії.

Організатор акредитованої освіти - фізичні або юридичні особи, які мають право планувати, надавати і оцінювати акредитовану освіту, засновану на діяльності системи акредитаціі.

Здоров'я пацієнта - ступінь, в якій стан здоров'я пацієнтів поліпшується у результаті змін у практичній діяльності учнів.

Продуктивність / ефективність практичної діяльності - (вживається як термін для оцінки ефективності навчання) - ступінь, в якій лікаpi можуть виконувати роботу у своїй практичній діяльності після БМО.

Істотна еквівалентність - це відносини між органами, які акредитують, засновані на загальних принципах і цінностях, при одночасному визнанні і прийнятті відмінностей.

Автор заявляе про відсутність конфлікту iнmepecis. 


\section{REFERENCES/JITEPATУPA}

1. Cervero RM, Gaines JK. (2015). The impact of CME on physician performance and patient health outcomes: an updated synthesis of systematic reviews. J Contin Educ Health Prof. 35: 131-138.

2. Humprhey-Murto S, Varpio L, Gonsalves C, Wood TJ. (2016). Using consensus group methods such as Delphi and Nominal Group in medical education research. Medical Teacher. 39 (1): 14-19. doi: 10.1080/0142159X.2017.1245856.

3. McMahon GT. (2016). What do I need to learn today? The evolution of CME. N Engl J Med. 374: 1403-1406

4. McMahon GT, Aboulsoud S, Gordon J, McKenna M, Meuser J, Staz M, Campbell CM. (2016). Evolving Alignment in International Continuing Professional Development Accreditation. J Contin Educ Health Prof. 36 (1): 22-26. doi: 10.1097/CEH.0000000000000075.

5. Mansouri M, Lockyer J. (2007). A meta-analysis of continuing medical education effectiveness. J Contin Educ Health Prof. 27: 6-15.

6. The Federation of State Medical Boards. (2014, March 11). FSMB Maintenance of Licensure (MOL) Task Force on Continuous Professional Development (CPD) Activities. URL: https://www.fsmb. org/Media/Default/PDF/FSMB/Foundation/FSMB_ MOL_Task_Force_on_CPD_Activities-FINAL_report.pdf. Accessed April $21,2016$.

7. Van de Wiel MW, Van den Bossche P, Janssen S et al. (2011). Exploring deliberatepractice in medicine: how do physicians learn in the workplace? Adv Health Sci Educ Theory Pract. 16: 81-95.

8. Varghese J. (2016). Boost for healthcare medical education. Gulf Times. URL: http://www.gulf-times.com/story/483904/Boost-for-healthcaremedical-education.

9. Whitehead TD, Lacey-Haun L. (2008). Evolution of accreditation in continuing nursing education in America. J Contin Educ Nurs. 39: 493-499.

Відомості про авторів:

Марушко Ростислав Володимирович - д.мед.н., зав. науково-організаційним відділенням ДУ «ІПАГ імені акад. О.М. Лук'янової НАМН України». Адреса: м. Київ, вул. П. Майбороди, 8; тел. (044) 484-18-71. http://orcid.org/0000-0001-7855-1679.

Стаття надійшла до редакції 15.04.2020 р.; прийнята до друку 01.06.2020 p.

\section{ДО УВАГИ АВТОРІВ!}

\section{AJITOPUTM PECCTPAIIII ORCID}

\section{Open Researcher and Contributor ID (ORCID) - міжнародний ідентифікатор науковця}

Створення єдиного реєстру науковців та дослідників на міжнародному рівні є найбільш прогресивною та своєчасною ініціативою світового наукового товариства. Ця ініціатива була реалізована через створення в 2012 році проекту Ореn Researcher and Contributor ID (ORCID). ORCID - це реєстр унікальних ідентифікаторів вчених та дослідників, авторів наукових праць та наукових організацій, який забезпечує ефективний зв'язок між науковцями та результатами їх дослідницької діяльності, вирішуючи при цьому проблему отримання повної і достовірної інформації про особу вченого в науковій комунікації.

Для того щоб зареєструватися в ORCID через посилання https://orcid.org/ необхідно зайти у розділ «For researchers» і там натиснути на посилання «Register for an ORCID iD».

В реєстраційній формі послідовно заповнюються обов'язкові поля: «First name», «Last name», «E-mail», «Re-enter E-mail», «Password» (Пароль), «Confirm password»

В перше поле вводиться ім'я, яке надане при народженні, по-батькові не вводиться. Персональна електронна адреса вводиться двічі для підтвердження. Вона буде використовуватися як Login або ім'я користувача. Якщо раніше вже була використана електронна адреса, яка пропонується для реєстрації, з'явиться попередження червоного кольору. Неможливе створення нового профілю з тією ж самою електронною адресою. Пароль повинен мати не менше 8 знаків, при цьому містити як цифри, так і літери або символи. Пароль, який визначається словами «Gоод» або «Strong» приймається системою..

Нижче визначається «Default privacy for new works», тобто налаштування конфіденційності або доступності до персональних даних, серед яких «Public», «Limited», «Private».

Далі визначається частота повідомлень, які надсилає ORCID на персональну електронну адресу, а саме, новини або події, які можуть представляти інтерес, зміни в обліковому записі, тощо: «Daily summery», «Weekly summery», «Quaterly summery», «Never». Необхідно поставити позначку в полі «I'm not a robot» (Я не робот).

Останньою дією процесу реєстрації є узгодження з політикою конфіденційності та умовами користування. Для реєстрації необхідно прийняти умови використання, натиснувши на позначку «I consent to the privacy policy and conditions of use, including public access and use of all my data that are marked Public».

Заповнивши поля реєстраційної форми, необхідно натиснути кнопку «Register», після цього відкривається сторінка профілю учасника в ORCID з особистим ідентифікатором ORCID ID. Номер ORCID ідентифікатора знаходиться в лівій панелі під ім'ям учасника ORCID.

Структура ідентифікатора ORCID являє собою номер з 16 цифр. Ідентифікатор ORCID - це URL, тому запис виглядає як http://orcid.org/ $\mathrm{xxxx}-\mathrm{xxxx}-\mathrm{xxxxxxxx}$.

Наприклад: http://orcid.org/0000-0001-7855-1679.

Інформацію про ідентифікатор ORCID необхідно додавати при подачі публікацій, документів на гранти і в інших науково-дослідницьких процесах, вносити його в різні пошукові системи, наукометричні бази даних та соціальні мережі.

Подальша робота в ORCID полягає в заповненні персонального профілю згідно із інформацією, яку необхідно надавати. 